\title{
Low level of stratospheric ozone near the Jharia coal field in India
}

\author{
Nandita D Ganguly \\ Department of Physics, St. Xavier's College, Ahmedabad 380 009, Gujarat, India. \\ e-mail: nanditad@icenet.net
}

The Indian reserve of coking coal is mainly located in the Jharia coal field in Jharkhand. Although air pollution due to oxides and dioxides of carbon, nitrogen and sulphur is reported to have increased in this area due to large-scale opencast mining and coal fires, no significant study on the possible impact of coal fires on the stratospheric ozone concentration has been reported so far. The possible impact of coal fires, which have been burning for more than 90 years on the current stratospheric ozone concentration has been investigated using satellite based data obtained from Upper Atmospheric Research Satellite (UARS MLS), Earth Observing System Microwave Limb Sounder (EOS MLS) and Ozone Monitoring Instrument (OMI) in this paper. The stratospheric ozone values for the years 1992-2007, in the 28-36 km altitude range near Jharia and places to its north are found to be consistently lower than those of places lying to its south (up to a radius of $1000 \mathrm{~km}$ around Jharia) by 4.0-20\%. This low stratospheric ozone level around Jharia is being observed and reported for the first time. However, due to lack of systematic ground-based measurements of tropospheric ozone and vertical ozone profiles at Jharia and other far off places in different directions, it is difficult to conclude strongly on the existence of a relationship between pollution from coal fires and stratospheric ozone depletion.

\section{Introduction}

Coal, a non-renewable source of energy, is formed from organic matter with high carbon content, which when exposed to certain conditions (temperature, moisture, oxygen, etc.) tends to ignite spontaneously at low temperature. This may occur naturally or the combustion process may be triggered by other causes. However, once a coal seam catches fire and efforts to stop it an early stage fail, it may continue to burn for tens to hundreds of years depending primarily on the availability of coal and oxygen. Apart from India, coal fires have been reported from nearly all parts of the world such as the US, Indonesia, South Africa, Australia, China and Germany. However, the nature and the magnitude of the problem differs from one country to another (Prakash 1996).
The coal-mine fire in the Jharia coal field was first detected in 1916. At present, more than 70 mine fires have been reported from this region. Coal mine fires are visible to the naked eye as open flames at night or at pre-dawn. They also erupt in the underground seams, which have large cracks that serve as channels for oxygen to the burning coal. One may also get to see smoke emitting vents, burnt/baked rocks, residual sulphur encrustation, dry soil and a local rise in the surface temperature. Smoke plumes from these fires contain poisonous gases such as oxides and dioxides of carbon, nitrogen and sulphur. Pixel-integrated temperatures of surface fires have been estimated to range between $217^{\circ} \mathrm{C}$ and $410^{\circ} \mathrm{C}$. The sub-pixel temperature corresponding to these areas have been found to range between $341.7^{\circ} \mathrm{C}$ and $731^{\circ} \mathrm{C}$ (Prakash 1996).

Keywords. Coal fire; pollution; ozone depletion. 
Table 1. Stratospheric ozone levels near Jharia $\left(23.75^{\circ} \mathrm{N}, 86.33^{\circ} \mathrm{E}\right)$, compared to those of far off monitoring stations on different occasions (source: UARS MLS and EOS MLS).

\begin{tabular}{rccccc}
\hline & & & Pressure \\
level & & $\begin{array}{c}\text { Lat./long. of } \\
\text { monitoring } \\
\text { stations }\end{array}$ & $\begin{array}{c}\text { \% of lower stratospheric } \\
\text { ozone near Jharia compared } \\
\text { to that of the monitoring } \\
\text { stations }\end{array}$ \\
\hline 1 & $14 / 03 / 1992$ & UARS MLS & 09.89 & $23.00^{\circ} \mathrm{N}, 57.10^{\circ} \mathrm{E}$ & 15.40 \\
2 & $27 / 06 / 2000$ & UARS MLS & 11.24 & $23.48^{\circ} \mathrm{N}, 106.86^{\circ} \mathrm{E}$ & 07.20 \\
3 & $25 / 10 / 2004$ & EOS MLS & 06.81 & $22.26^{\circ} \mathrm{N}, 82.52^{\circ} \mathrm{E}$ & 07.10 \\
4 & $08 / 01 / 2005$ & EOS MLS & 04.64 & $22.26^{\circ} \mathrm{N}, 87.05^{\circ} \mathrm{E}$ & 10.62 \\
5 & $26 / 01 / 2005$ & EOS MLS & 10.00 & $22.26^{\circ} \mathrm{N}, 85.81^{\circ} \mathrm{E}$ & 05.70 \\
6 & $16 / 04 / 2005$ & EOS MLS & 10.00 & $22.26^{\circ} \mathrm{N}, 85.79^{\circ} \mathrm{E}$ & 12.22 \\
7 & $19 / 06 / 2005$ & EOS MLS & 14.67 & $22.26^{\circ} \mathrm{N}, 85.83^{\circ} \mathrm{E}$ & 06.70 \\
8 & $19 / 07 / 2005$ & EOS MLS & 10.00 & $22.26^{\circ} \mathrm{N}, 86.98^{\circ} \mathrm{E}$ & 06.70 \\
9 & $16 / 09 / 2005$ & EOS MLS & 10.00 & $25.22^{\circ} \mathrm{N}, 86.61^{\circ} \mathrm{E}$ & 06.50 \\
10 & $25 / 10 / 2005$ & EOS MLS & 10.00 & $22.26^{\circ} \mathrm{N}, 85.75^{\circ} \mathrm{E}$ & 07.68 \\
11 & $29 / 01 / 2006$ & EOS MLS & 14.67 & $22.26^{\circ} \mathrm{N}, 85.83^{\circ} \mathrm{E}$ & 04.00 \\
12 & $28 / 04 / 2006$ & EOS MLS & 14.67 & $25.22^{\circ} \mathrm{N}, 86.50^{\circ} \mathrm{E}$ & 08.97 \\
13 & $03 / 05 / 2006$ & EOS MLS & 14.67 & $22.26^{\circ} \mathrm{N}, 86.98^{\circ} \mathrm{E}$ & 07.72 \\
14 & $20 / 06 / 2006$ & EOS MLS & 06.81 & $22.25^{\circ} \mathrm{N}, 87.11^{\circ} \mathrm{E}$ & 19.90 \\
15 & $02 / 01 / 2007$ & EOS MLS & 06.81 & $20.77^{\circ} \mathrm{N}, 89.33^{\circ} \mathrm{E}$ & 12.50 \\
16 & $12 / 01 / 2007$ & EOS MLS & 10.00 & $22.26^{\circ} \mathrm{N}, 84.11^{\circ} \mathrm{E}$ & \\
\hline
\end{tabular}

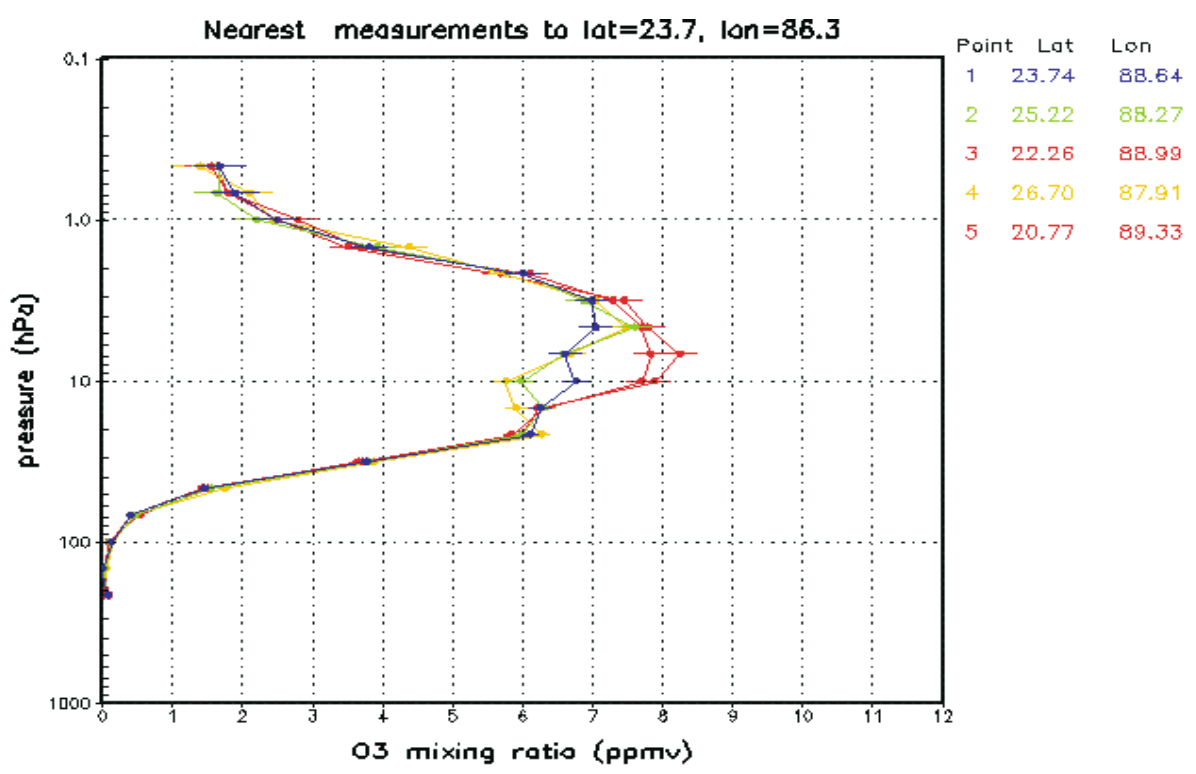

Figure 1. A typical vertical $\mathrm{O}_{3}$ profile from EOS MLS to the east of Jharia $\left(23.75^{\circ} \mathrm{N}, 86.33^{\circ} \mathrm{E}\right)$ and monitoring stations lying to the northeast and southeast of Jharia on $2 / 1 / 2007$.

\section{Monitoring site and measurements}

The Jharia coal field in Jharkhand is about $250 \mathrm{~km}$ NW of Kolkata, and about $1150 \mathrm{~km}$ SE of Delhi. It is confined between latitudes $23.63^{\circ} \mathrm{N}$ and $23.83^{\circ} \mathrm{N}$ and longitudes $86.12^{\circ} \mathrm{E}$ and $86.5^{\circ} \mathrm{E}$. It stretches about $38 \mathrm{~km}$ from east to west and $19 \mathrm{~km}$ from north to south in the shape of a sickle. It is an exclusive storehouse of prime coke coal in the country, comprising of 23 large underground and nine large open cast mines (Prakash 1996). The region has a tropical monsoon type climate (Ghose \& Majee 2000). Westerlies and northwesterlies are the predominant wind directions in this region, as 


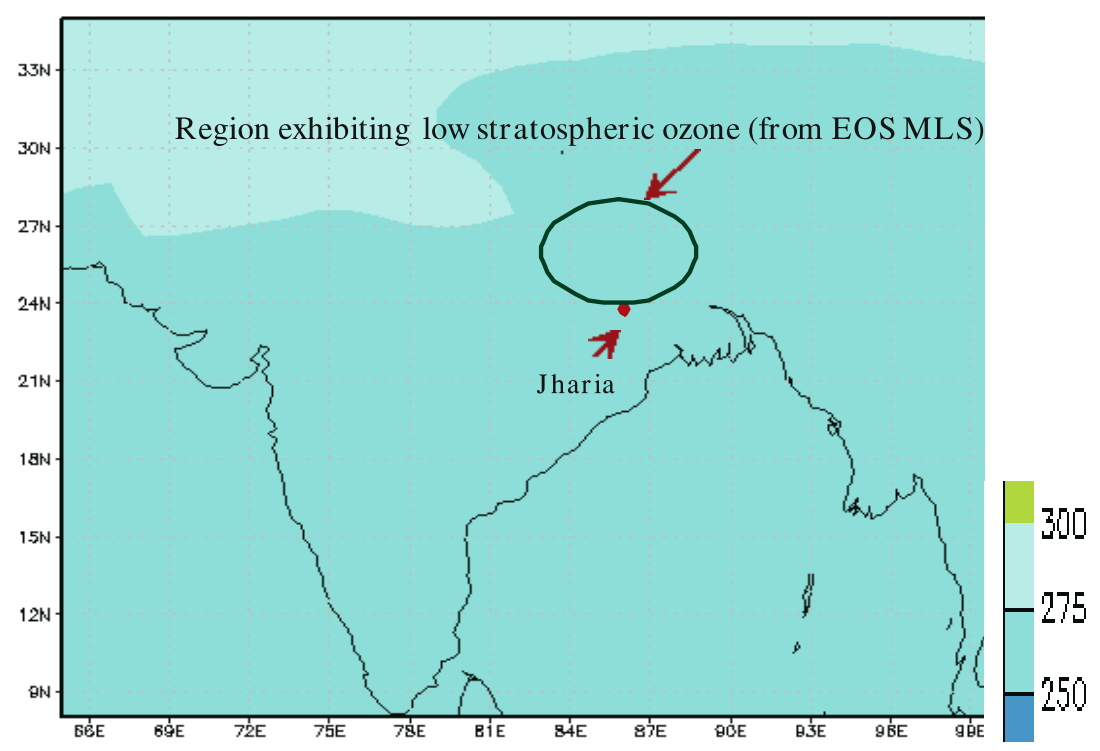

Figure 2. Total column $\mathrm{O}_{3}$ obtained from OMI for the period 1/1/2005-31/12/2005 and observed region of stratospheric ozone depletion (from 2004-2007) from EOS MLS.

observed from an average data of 30 years at Dhanbad meteorological station (Ghose \& Bannerjee 1995).

The ozone data obtained from Ozone Monitoring Instrument (OMI) has been used to investigate variations in the total ozone concentration. The OMI on Aura satellite provides daily highresolution global maps of ozone.

The vertical ozone profiles have been obtained from Upper Atmosphere Research Satellite (UARS MLS) and Earth Observing System Microwave Limb Sounder (EOS MLS). The first MLS experiment (UARS MLS) on NASA's Upper Atmosphere Research Satellite was launched on 12 September, 1991. After 15 March 1994, the measurements became increasingly sparse in order to conserve the lifetime of the MLS antenna scan mechanism and UARS power. It used solar occultation to measure vertical profiles of $\mathrm{O}_{3}$. Latitudinal coverage was from $80^{\circ} \mathrm{S}$ to $80^{\circ} \mathrm{N}$ over the course of one year and the altitude range of the measurements extended from about 15 to $130 \mathrm{~km}$. Experiment operations were essentially flawless, and all performance criteria either met or exceeded specifications (http://mls.jpl.nasa.gov/). The last data were obtained on 25 August 2001. The second MLS experiment (EOS MLS) on the NASA Earth Observing System Aura mission, was launched on 15 July 2004. It started taking observations from 13 August 2004, with excellent performance to date in all portions of the instrument (http://mls.jpl.nasa.gov/). The MLS measurements are made globally day and night by shorter-wavelength infrared, visible and ultraviolet radiations and can be obtained even in the presence of ice clouds and aerosol that prevent such measurements.

\section{Results and discussions}

The stratospheric ozone profiles obtained from UARS MLS and EOS MLS for the years 1992, 2000 and $2004-2007$, in $14-4.6 \mathrm{hPa}$ pressure range (i.e., 28-36 km altitude range) near Jharia and places lying to its north are found to be consistently lower than those of places lying to its south (up to a distance of $1000 \mathrm{~km}$ from Jharia), by $0.35-1.67 \mathrm{ppmv}$ (i.e., 4-20\%) as shown in table 1. A typical vertical $\mathrm{O}_{3}$ profile obtained from EOS MLS to the east of Jharia and monitoring stations lying to its northeast and southeast on $2 / 1 / 2007$ is shown in figure 1 . This is contradictory to the well-established fact that columnar ozone concentration increases with latitude. Satellite-based profiles near Jharia could not be obtained from UARS MLS or EOS MLS on occasions other than those mentioned in table 1.

Ghose and Majee (2000) have reported that the $\mathrm{NO}_{2}$ and $\mathrm{SO}_{2}$ levels at Jharia exceeded the permissible limits specified by the Central Pollution Control Board (CPCB) during summer, postmonsoon and winter, but not in the rainy season, which they attributed due to the washing out of pollutants by rain water. They have also observed that the $\mathrm{NO}_{x}$ concentrations at the downwind locations were lower compared to those of upwind locations. Chatterjee et al (2007), studied the changes in the net lateral propagation of coal fire from 1992-2001 at Jharia. They have observed 
that the net lateral propagation was erratic and did not follow any general pattern. During 19921996 , the net propagation was towards south and west whereas during 1996-2001, it was towards north.

The observed low stratospheric ozone near Jharia and places to its north, may be because, the smoke plume from these fires contain gases such as methane, oxides and dioxides of carbon, nitrogen and sulphur. These gases which are being continuously released into the air, gradually infiltrate all parts of the atmosphere including the stratosphere over a period of several decades and are transported polewards by atmospheric winds. The lifetime of methane in the atmosphere is 10-12 years, and that of nitrous oxide is almost 100 years before it is destroyed in the stratosphere. They are broken down in the stratosphere by the high levels of solar UV radiation, freeing extremely reactive $\mathrm{NO}$ and $\mathrm{OH}$, which take part in a complex series of reactions leading to ozone depletion. Sulphur dioxide is rapidly converted into sulphuric acid aerosol, increasing the rate of ozone depletion.

The total ozone values obtained from OMI for Jharia (figure 2) do not show any difference from those for other nearby locations in the upwind and downwind direction. This may be because the difference between the total ozone values at Jharia (and places to its north) from those of other nearby locations lying to its south on most occasions is less compared to the resolution of the OMI measurements, which is of the order of 25 Dobson units.

\section{Conclusions}

The possible impact of coal fires, which have been burning since several decades on the current stratospheric ozone concentration has been investigated in this paper. The stratospheric ozone profiles obtained from UARS MLS and EOS MLS for the years 1992-2007, in the $28-36 \mathrm{~km}$ altitude range for places lying to the north of Jharia are found to be consistently lower than those lying to its south up to a radius of $1000 \mathrm{~km}$ around Jharia by $4-20 \%$. This may be because, the smoke plume from these fires contain gases, which take part in a complex series of reactions leading to stratospheric ozone depletion. This low stratospheric ozone level around Jharia is being observed and reported for the first time. However, due to lack of systematic ground-based measurements of tropospheric ozone and vertical ozone profiles at Jharia and other far off places in different directions, it is difficult to conclude strongly on the existence of a relationship between pollution from coal fires and stratospheric ozone depletion.

\section{Acknowledgements}

The author wishes to convey her gratitude to the honourable reviewers for their valuable suggestions and NASA/NOAA for providing OMI ozone data. The vertical $\mathrm{O}_{3}$ profiles from UARS MLS and EOS MLS used in this study were obtained using the GES-DISC Interactive Online Visualization and Analysis Infrastructure.

\section{References}

Chatterjee R S, Wahiduzzaman Md, Shah A, Raju E V R, Lakhera R C and Dadhwal V K 2007 Dynamics of coal fire in Jharia Coalfield, Jharkhand, India during the 1990's as observed from space; Curr. Sci. 92(1) 61-68.

Ghose M K and Bannerjee S K 1995 Status of air pollution caused by coal washery project in India; Environmental monitoring and assessment 38 97-105.

Ghose M K and Majee S R 2000 Assessment of the impact on the air environment due to opencast coal miningan Indian case study; Atmospheric Environment 34(17) 2791-2796.

Prakash A 1996 Remote sensing - GIS based Geoenvironmental studies in Jharia Coalfield, India, with special reference of coalmine fires. Ph.D. Thesis, Department of Earth Sciences, UOR, Roorkee, India, 194. http://mls.jpl.nasa.gov/ 